\title{
Pelatihan Jarimatika Bagi Guru Di SD Negeri 2 Indralaya Utara
}

\author{
Puji Ayurachmawati ${ }^{1}$, Sunedi ${ }^{2}$, Marvinda Rizki Dita Dirgantara ${ }^{3}$, \\ Sylvia Lara Syaflin ${ }^{4}$, Miftha Indasari ${ }^{5}$, Adrianus Dedi ${ }^{6}$ \\ Program Studi Pendidikan Guru Sekolah Dasar, Fakultas Keguruan dan Ilmu Pendidikan, Universitas \\ PGRI Palembang \\ Pujiar29@gmail.com
}

\begin{abstract}
ABSTRAK
Pelajaran matematika merupakan keterampilan dasar yang harus dikuasai siswa sebelum mempelajari mata pelajaran sains. Masih banyak siswa mengalami kesulitan dalam belajar matematika hal ini dapat dilihat dari hasil belajarnya serta sikapnya dalam mengikuti pembelajaran. Sebenarnya tidak demikian, apa bila guru dalam tugasnya memiliki keterampilan dan kemampuan yang dapat menarik minat siswa dalam belajar terutama behitung kali, bagi, tambah dan kurang. Metode jarimatika sangat baik digunakan guru karena jarimatika dapat memudahkan siswa dalam berhitung baik dari angka satuan, puluhan hingga ratusan dengan menggunakan jari tangan. Metode pada pelatihan ini menggunakan metode ceramah, workshop, dan Tanya jawab dimana angket digunakan sebagai nilai ukur ketercapaian kegiatan. Hasil pelatihan menunjukan bahwa metode jarimatika dapat dijadikan alternative pembelajaran bagi guru SD kepada siswa dalam meningkatkan kemampuan berhitung kali, bagi, tambah dan kurang. Selama kegiatan semua guru aktif dalam pelatihan serta kemampuan guru dalam penggunaan metode jarimatika sangat baik. Terlihat pada angket yang diberikan bahwa didapat hasil $88 \%$ guru memamhami metode jarimatika bahkan melebih $85 \%$ dari target yang diharapakan.
\end{abstract}

Kata kunci: Pelatihan, Metode jarimatika

\section{ABSTRACT}

Mathematics is a basic skill that students must master before learning science subjects. There are still many students who have difficulty learning mathematics, this can be seen from their learning outcomes and their attitudes in participating in learning. Actually this is not the case, what if the teacher in his duties has the skills and abilities that can attract students' interest in learning, especially counting, dividing, adding and less. The Jarimatika method is very good for the teacher to use because Jarimatika can make it easier for students to count from unit numbers, tens to hundreds using their fingers. The method in this training uses the method of lectures, workshops, and question and answer where questionnaires are used as a measure of activity achievement. The results of the training show that the Jarimatika method can be used as an alternative learning method for elementary school teachers to students in increasing their numeracy skills, divide, add and less. During the activity, all teachers were active in training and the teacher's ability to use the Jarimatika method was very good. It can be seen in the questionnaire given that the results obtained that $88 \%$ of teachers understand the Jarimatika method even more than $85 \%$ of the expected target.

Keywords: Training, Jarimatika method

\section{PENDAHULUAN}

Dalam pembelajaran matematika, khususnya berhitung tidak jarang ditemukan banyak kesulitan karena tidak banyak siswa yang tertarik dengan perhitungan(Riyanti et al., 2017). Bukan hal yang mengherankan lagi ketika matematika dianggap sebagai pelajaran paling sulit oleh siswa karena sebagian besar materinya memerlukan perhitungan

Umumnya matematika merupakan mata pelajaran yang tidak disenangi. Ada kesan mata pelajaran matematika adalah salah satu mata pelajaran yang sulit, sehingga siswa-siswa kurang berminat mempelajarinya. (Dewi et al., 2020) mengemukakan bahwa matematika masih saja dianggap sebagai bidang studi yang menakutkan oleh banyak siswa, dan masih banyak siswa yang memperoleh hasil belajar yang kurang memuaskan. Sampai saat ini matematika masih dirasakan sebagai momok oleh sebagian siswa, termasuk bagi siswa SD.

Indikasinya adalah masih banyak siswa SD mengalami kesulitan dalam belajar matematika. Hal ini dapat dilihat dari hasil belajarnya, keluhan, serta sikapnya dalam mengikuti pembelajaran. Tidak dapat 
dipungkiri dengan menunjuk pada hasil belajar siswa yang masih rendah. Sebenarnya tidak demikian, apa-bila guru dalam tugasnya untuk membuat siswa memahami dan termotivasi untuk mempelajari matematika terutama pembelajaran berhitung $\mathrm{KaBaTaKu}$ (Kali Bagi Tambah Kurang). Menurut (Nasution et al., 2016) pembelajaran $\mathrm{KaBaTaKu}$ (Kali Bagi Tambah Kurang) Sebaiknya menggunkan metode jarimatika, hal ini dikarnakan metode jarimatika dapat memudahkan siswa dalam berhitung baik dari angka satuan, puluhan hingga ratusan dengan menggunakan jari tangan.

Jarimatika (singkatan dari jari dan aritmatika) adalah metode berhitung dengan menggunakan jari tangan (Wulandari, 2008.17). Metode ini dikembangkan kembali oleh Septi Peni Wulandani sekitar tahun 2004. Meski hanya menggunakan jari tangan, tapi dengan metode jarimatika mampu melakukan operasi bilangan $\mathrm{KaBaTaKu}$ (Kali Bagi Tambah Kurang) sampai dengan ribuan (jarimatika center Indonesia I).

Jarimatika adalah sebuah cara sederhana dan menyenangkan mengajarkan berhitung dasar kepada anak-anak menurut kaidah : Dimulai dengan memahamkan secara benar terlebih dahulu tentang konsep bilangan, lambang bilangan, dan operasi hitung dasar, kemudian mengajarkan cara berhitung dengan jari-jari tangan (Indah, 2015). Prosesnya diawali, dilakukan dan diakhiri dengan gembira. Metode ini sangat mudah diterima anak. Mempelajarinya pun sangat mengasyikkan, karena jarimatika tidak membebani memori otak dan "alat"nya selalu tersedia bahkan saat ujian karena alatnya adalah jari tangan kita sendiri (Salsinha et al., 2019). Beberapa penelitian menunjukkan hasil efektif dalam penggunan jari matika dalam kemampuan berhitung siswa.

Marianti (2017) pada penelitian tindakan kelas yang dilakukan untuk penggunaan jarimatika dalam meningkatkan kemampuan berhitung diperoleh hasil efektif dengan presentasi keberhasilan dalam kelas mencapai 90\%. Sama halnya dengan (Idham Sumirat, 2017) menyatakan bahwa dengan penggunaan konsep jarimatika pada proses pembelajaran di SD kelas I dan II menyatakan bahwa metode jarimatika efektif dalam meningkatkan pemahaman konsep penjumlahan dan pengurangan siswa kelas I dan II Sekolah Dasar dengan capaian peningkatan sebesar $91,89 \%$ di siklus II.
Penggunaan jarimatika bisa menjadi alternatif dalam memudahkan mengasa kemampuan berhitung matematika siswa. Jarimatika memiliki peran dalam meningkatkan kakatifan belajar siswa (Ariati, 2017). Konsep sederhana dalam penerapan jarimatika yang menyenangkan dalam mengajarkan konsep berhitung dasar kepada anak-anak menurut kaidah-kaidah berikut: 1. Dimulai dengan memahami konsep bilangan, lambang bilangan dan operasi hitung dasar 2. Mengajarkan cara berhitung dengan jari-jari tangan. 3. Prosesnya diawali, dilakukan dan diakhiri dengan gembira (Sulistiyaningsih, N. 2018).

Pada dasarnya penggunaan jarimatika dapat membatuh guru dalam proses pembelajaran berhitung siswa. sehingga guru memliki metode baru dalam menerapkan pembelajaran yang sesuai dengan karakteristik siswa seperti pemanfaatan alat peraga. Pemanfaatan alat peraga sederhana seperti jari tangan akan meningkatkan minat belajar siswa serta dapat menjadikan siswa berpikir kreatif, aktif dan menyenangkan. Guru dapat lebih mudah melakukan pembelajaran berihitung $\mathrm{KaBaTaKu}$ (Kali Bagi Tambah Kurang). sehingga jari tangannya benar-benar menyerupai kalkulator, maka metode ini diberi nama JARIMATIKA yang artinya Jari Pintar Berhitung atau Berhitung dengan Jari.

Secara umum tujuan PKM ini adalah para dosen memberikan pelatihan metode jarimatika bagi guru Sekolah Dasar Negeri 2 Indralaya utara. Sehingga guru memliliki metode lain yang dapat menumbuhkan minat belajar berhitung siswa serta dapat meningkatkan kemampuan dan keterampilan siswa dalam berhitung terutaman $\mathrm{KaBaTaKu}$ (Kali Bagi Tambah Kurang). Sedangkan secara spesifik tujuan yang hendak dicapai adalah: (1). Melatih keterapilan guru dalam berhitung metode jarimatika. (2). Dapat menambah wawasan guru dalam pembelajaran matematika. (3). Mengembangkan kemampuan dosen dalam melaksanakan Tri Dharma perguruan tinggi khususnya pelaksanaan pengabdian kepada masyarakat.

\section{METODE KEGIATAN}

Kegiatan pelatihan jarimatika bagi guru SD negeri 2 indralaya utara di laksanakan selama satu hari yaitu pada hari Selasa, 20 Oktober 2020 bertempat di SD Negeri 2 Indralaya utara. Khalayak sasaran pada kegiatan pengabdian pada masyarakat ini yaitu guru-guru di SD Negeri 89 Indralaya Utara 
semester ganjil tahun ajaran 2020/2021 sebanyak 45 orang dengan durasi 5 jam.

Panitia penyelenggara adalah LPPKMK Universitas PGRI Palembang. Mekanisme kegiatan ini dilaksanakan berdasarkan rancangan umum kegiatan pelatihan yang dikoodinasi oleh LPPkMK Universitas PGRI Palembang.

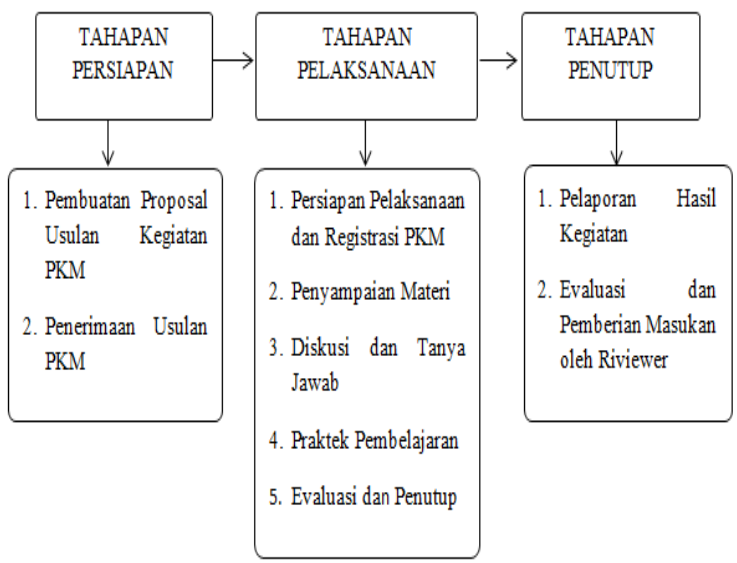

Bagan 1. Skema tahapan PKM

Penyampaian materi kegiatan ini dilaksanakan dengan tiga metode sebagai berikut:

a. Metode ceramah

Metode ceramah digunakan untuk kegiatan tahap awal yang berkaitan dengan pemahaman guru tentang (1) Pengenalan metode jarimatika, (2) Penggunan metode jarimatika dalam pembelajaran matematika

dan (3) Cara menggunakan jari tangan untuk jarimatika operasi $\mathrm{KaBaTaKu}$ (Kali Bagi Tambah Kurang).

b. Workshop

Kegiatan ini termasuk kegiatan inti yang berkaitan dengan pemahaman dan aktualisasi kemampuan guru pada proses pelatihan metode jarimatika dalam pembelajaran matematika. Kegiatan ini meliputi (1) praktek dan latihan dasardasar pengenalan jarimatika, dan (2) praktek penggunaan jarimatika pada operasi hitung penjumlahan, pengurangan, perkalian dan pembagian.

c. Metode tanya jawab

Metode ini digunakan untuk menggali tingkat pemahaman guru terhadap metode jarimatika yang disampaikan oleh pemateri. Pertanyaan-pertanyan yang diberikan guru tentang metode jarimatika dapat menjadi nilai ukur pemahaman guru terhadap metode jarimatika.
Kegiatan pengabdian kepada masyarakat dosen Program Studi Pendidikan Guru Sekolah Dasar ini telah dilaksanakan pada hari Selasa, 20 Oktober 2020 dari pukul 08.00 12.00 WIB, bertempat di Ruang Kelas SD Negeri 2 Indaralaya Utara. Jl. PalembangPrabumulih Km.32 Timbangan Indralaya Utara. Kegiatan pengabdian pada masyarakat ini telah diikuti oleh guru -guru SD Negeri 2 Indralaya Utara dengan jumlah peserta sebanyak 45 orang.

Berikut pengenalan jarimatika dengan lambang-lambang yang digunakan di dalam Jarimatika. diawali dengan tangan kanan yang merupakan lambang bilangan satuan $1-9$.

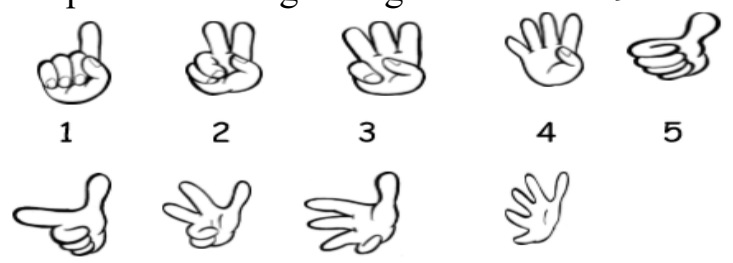

Untuk jari tangan kiri bernilai puluhan

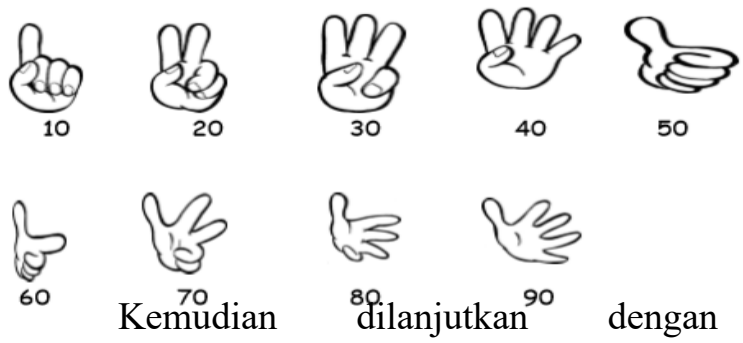

pengoperasian jarimatika dengan menggunakan jari tangan tersebut. Operasi yang pertama yaitu Operasi penjumlahan contohnya: $3+4$. Cara: Buka jari kanan 3 kemudian buka lagi sebanyak 4 jari, karena sudah tidak cukup maka untuk memperoleh angka 5 buka jari jempol yang memiliki angka 5. Karena jempol memiliki angka 5 dan jari bergerak sebanyak 4 maka akan didapat hasilnya 7.

Sedangkan untuk operasi penguragan jarimatika dapat menggunakan jari tangan hitungan mundur atau dilipat kembali sebanyak pengurangan. Contoh: $7-3$. Cara: Buka jari kanan benilai 7 kemudian tutup/kurang 3 dengan cara tutup jempol, karena jempol memiliki angka 5 maka untuk memperoleh 3, tutup jempol lalu buka dua jari kanannya maka didapat jari bernilai 4 .

Berbeda dengan operasi penjumlahan dan pengurangan sebelumnya, untuk operasi perkalian dan pembagian nilai jari tangan berbeda. 


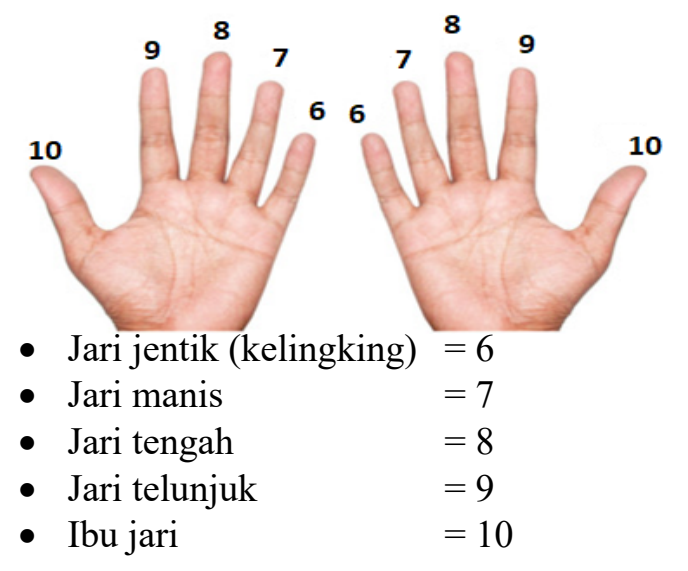

Rumus: $(\mathrm{P} 1+\mathrm{P} 2)+(\mathrm{S} 1 \times \mathrm{S} 2)$

Ket: $\quad \mathrm{P}=$ Puluhan

$\mathrm{S}=$ Satuan

Operasi perkalian $6 \times 7$.

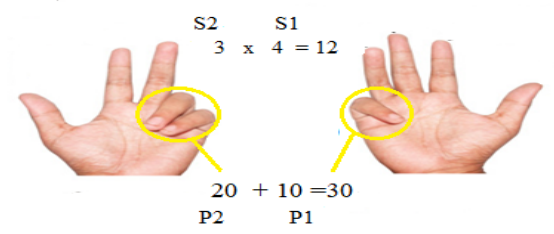

Caranya: Lipatlah jari tangan kiri bernilai 7 , kemudian lipat jari tangan kanan bernilai 6. Jari yang dilipat tangan kanan dan kiri bernilai puluhan dan jari tangan yang berdiri bernilai satuan (kanan dan kiri). Selanjutnya jumlahkan nilai jari yang dilipat $(20+10=30)$. Kalikan banyak jari yang tidak dilipat tangan $(4 \times 3=12)$. Hasil penjumlahan tangan yang dilipat (puluhan) dijumlahan dengan hasil kali tangan yang tidak dilipat ( 30 $+12=42$ ). Maka hasil perkalian jarimatika $7 \mathrm{x}$ 6 adalah 42 .

Sedangankan operasi pembagian jari tengan memiliki 2 angka dapat dilihat pada gambar berikut:

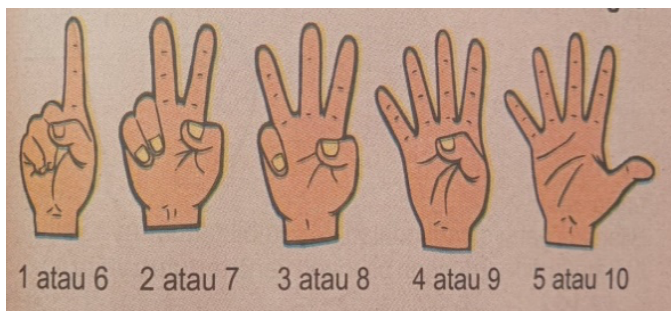

Contoh: $24: 6=\ldots$

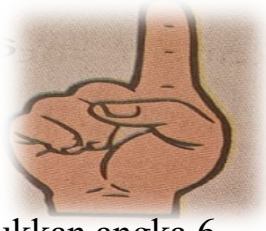

Tangan kanan menunjukkan angka 6
Jumlah jari yang ditutup 4. Bilangan yang dibagi adalah 24, ambil satuannya yaitu 4 . Satuan dibagi dengan bilangan yang tertutup yaitu 4.

Jadi $4: 4=1$

Proses pelatihan jarimatika ini dilakukan satu kali pertemuan. Para guru sangat antusias dan menyenangkan melaksanakan kegiatan demi kegiatan. Hal ini dikarenakan para guru belum tahu sama sekali dengan metode jarimatika yang mana, dengan menggunakan jarimatika guru dapat melakukan berbagai operasi hitung bilangan dengan mudah diantaranya; penjumlahan, pengurangan, perkalian dan pembagian.

Kegiatan pertama menjelaskan materi penjumlahan, pengurangan, perkalian dan pembagian bilangan satuan dan puluhan. Sebelum pembelajaran materi tersebut dimulai dilakukan lebih dahulu pengenalan jarimatika yang disampaikan oleh pemateri diantaranya nama-nama jari, nilai tiap-tiap jari, dan pengunaan jari.

Kemudian dilanjutkan dengan tahap praktek jarimatika. Pada kegiatan praktek guru terlihat mulai memahami pengunaan jarimatika baik untuk operasi penjumlahan, pengurangan, perkalian dan pembagaian. Terlihat beberapa guru dengan mudah menghitung operasi bilangan dengan metode ini baik angka satuan ataupun puluhan. Pemahaman jarimatika dapat ini dapat menjadi pembelajran alternatif bagi guru serta memudahkan guru dalam proses pembelajaran di kelas khususnya operasi KaBaTaKu (Kali Bagi Tambah Kurang).

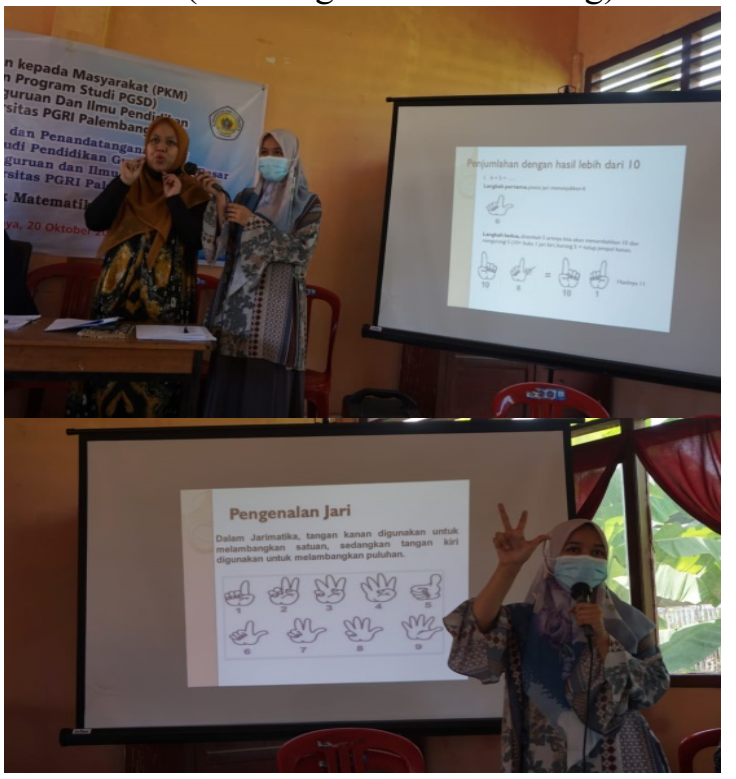

Gambar: 1. kegiatan persentasi metode jarimatika 


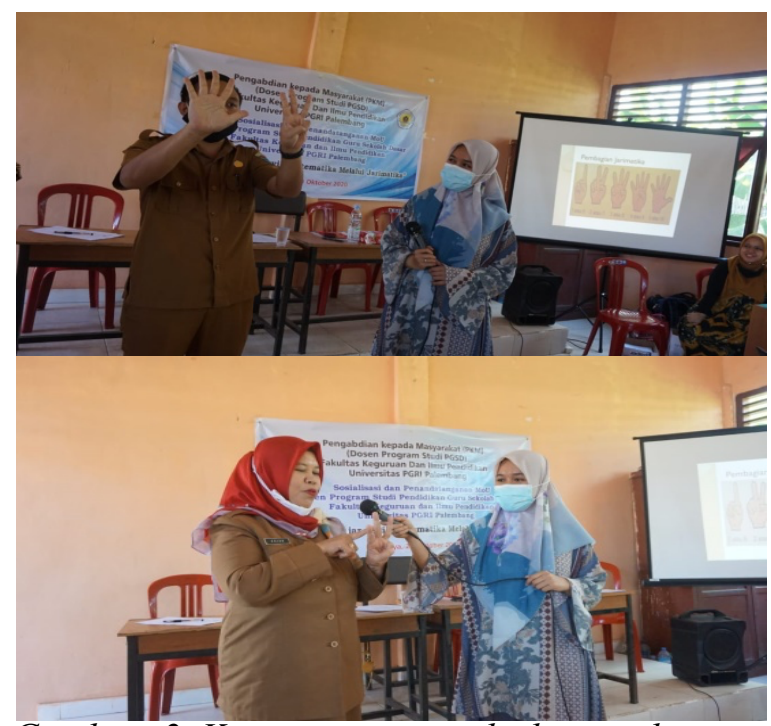

Gambar: 2. Kegiatan guru praktek metode jarimatika

Selama kegiatan berlangsung cukup banyak pertanyaan dari guru atau peserta. bahkan tidak jarang materi yang dilatihkan justru menjadi jauh melebar dikarenakan antusiasme dan keingintahuan peserta yang sangat tinggi terhadap penggunaan metode ini. Setelah memahami metode jarimatika ini guru dengan mudah mengoperasikan penjumlahan dan pengurangan contohnya: $12+9,20+$ $51,35-13,18-7$ serta bilangan yang lebih besar. Begitu juga dengan perkalian dan pembagian guru dengan mudahnya mengetahui hasil dari perkalian $6 x 7,8 \times 8,12 x 14,15 \times 15,20 \times 18 \quad$ serta pembagian bilangan 36: 6, 72: 9 dan seterusya. bahkan bilangan lebih besarpun dapat dihitung cepat dengan jarimatika.

Setelah dilakukan pelatihan tidak lupa pemateri memberikan angket kepada guru sebagai perserta untuk dapat mengetahui berapa persen keberhasilan pelatihan metode jarimatika. Dari angket tersebut didapat hasil $88 \%$ guru memamhami metode jarimatika bahkan melebih $85 \%$ dari target yang diharapakan. Hal ini dapat dikatakan bahwa metode jarimatika sangat baik digunakan sebagai alternatif pembelajaran operasi bilangan khususnya KaBaTaKu (Kali Bagi Tambah Kurang).

Walaupun 12\% lagi masih ada guru yang belum begitu memahami semua operasi jarimatika setidaknya melalui kegiatan pelatihan ini menjadi suatu rangsangan dan dasar bagi guru untuk mengeksplorasi lebih jauh serta dapat mengaplikasikanya pada proses pembelajaran matematika di kelas.

\section{KESIMPULAN \& SARAN}

Jarimatika adalah sebuah cara sederhana dan menyenangkan mengajarkan berhitung dasar kepada anak-anak. Penggunaan jarimatika dapat membatuh guru dalam proses pembelajaran berhitung siswa. Dari pelatihan ini diharapkan guru dapat lebih mudah melakukan pembelajaran berihitung KaBaTaKu (Kali Bagi Tambah Kurang). Dengan demikian guru memiliki alternative atau cara baru dalam proses pembelajaran operasi hitung tersebut. Hal ini dikarnakan jarimatika dapat memacu minat dan semagat belajar siswa serta dapat menciptakan pembelajaran yang lebih menyenangkan.

\section{DAFTAR PUSTAKA}

Ariati, J. (2017). Pengaruh Metode Jarimatika Terhadap Prestasi Belajar Matematika Siswa Tunanetra Sekolah Dasar SLB Negeri I Pemalang. Jurnal Psikologi Universitas Diponegoro, 115-125. https://doi.org/10.14710/jpu.10.2.115125

Dewi, V. F., Suryana, Y., \& Hidayat, S. (2020). Pengaruh Penggunaan Jarimatika Terhadap Kemampuan Berhitung Perkalian Peserta Didik Kelas IV Sekolah Dasar. EduBasic Journal: Jurnal Pendidikan Dasar, 2(2), 79-87. https://doi.org/10.17509/ebj.v2i2.26816

Idham Sumirat, T. W. (2017). Pengaruh Praktik Jarimatika Terhadap Keterampilan Berhitung Perkalian Pada Siswa Kelas Ii Sd. Jurnal Kreatif: Jurnal Kependidikan Dasar, 7(1).

Indah, R. P. (2015). Efektivitas Metode Jarimatika Untuk Meningkatkan Kemampuan Berhitung Siswa Sekolah Dasar Kelas III. DutaCom Journal. 8(2): $1-7$

Mariyati, Y., Sari, N. 2017. Efektifitas Penggunaan Jarimatika dalam Meningkatkan Ketrampilan Berhitung Matematika Kelas III SD N 2 Tamansari. Jurnal Teknologi Pendidikan, 2 (1) : 30-35

Nasution, T. K., Surya, E., Pasca, P., Prodi, S., \& Matematika, P. (2016). Penerapan Teknik Jarimatika Dalam Upaya Perkalian Bilangan. II(2), 136-147.

Riyanti, R., Sutama, S., \& Maryadi, M. (2017). Manajemen Pembelajaran Matematika di SD Negeri Mangkubumen 83 Surakarta. Jurnal VARIDIKA, 29(1), 65-74. https://doi.org/10.23917/varidika.v29i1.5 150 
Salsinha, C. N., Binsasi, E., \& Bano, E. N. (2019). Peningkatan kemampuan berhitung dengan metode jarimatika di Sekolah Dasar Negeri (SDN) Neonbat Nusa Tenggara Timur. Transformasi: Jurnal Pengabdian Masyarakat, 15(2), 73-84.

https://doi.org/10.20414/transformasi.v15 i 2.1302
Sulistiyaningsih, N. 2018. Peningkatan Keaktifan Belajar Matematika dengan Metode Jarimatika. Jurnal Pendidikan Riset \& Konseptual, 2 (1) : 57-6

Wulandari, S. P. (2008). Jarimatika Perkalian dan Pembagian. Tangerang: PT Kawan Pustaka. 